Reseña

\section{Annunziata Berrino y Carlos Larrinaga (coords.). Italia e Spagna nel turismo del Secondo Dopoguerra. Società, politiche, istituzioni ed economía. Milano, Franco Angeli, 2021, 272 pp. ISBN: 978-8835109853.}

El presente libro ofrece un análisis histórico comparado del turismo entre Italia y España, atendiendo a los aspectos políticos, económicos y sociales en el comienzo de la masificación del sector, que comprende los años del primer franquismo para España (1939-1958) y el periodo que siguió a la Segunda Guerra Mundial para Italia (1945-1960).

Junto a sus peculiaridades, se registran puntos de analogía, ya que en Italia, como entonces en el franquismo vigente en España, el turismo se había desenvuelto antes de la Segunda Guerra Mundial bajo un régimen de importante intervención pública generador de un proceso de conformación turística creciente en el mundo mediterráneo, otorgando un activo destino a la sociedad y economía europea.

La obra, después de una acertada introducción de los coordinadores, se divide en tres partes. La primera trata de instituciones políticas; la segunda de sociedad y economía, y la tercera y última atiende a las fuentes. Cada artículo viene desglosado en apartados, conclusiones y bibliografía.

La profesora Berrino de la Universidad Federico II de Nápoles presenta el artículo "Ĺistituzione dell'Alto commissariato per il turismo nell'Italia del secondo dopoguerra». Esta referida institución se creó en 1947 por el Gobierno de Alcide De Gasperi, quien mostró una política inclusiva y ser capaz de absorber el sector turístico, sin operar cambios radicales respecto a la etapa anterior; no obstante, en 1950, Amintore Fanfani expresaría elementos revisionistas que fueron acogidos por la Cámara de Comercio de Italia.

Por su parte, el profesor de la Universidad de Granada, Carlos Larrinaga, estudia «Los límites de la actividad turística privada en la España del primer franquismo, 1932-1952. El Sindicato Nacional de Hostelería». Este ensayo nos recuerda que el turismo en España, como el resto de la economía, experimentó las rigideces del control establecido por los primeros Gobiernos del franquismo, ya que la actividad hostelera estuvo sujeta a las disposiciones de la Dirección General del Turismo; pero sirvió, señala Larrinaga, para tratar de armonizar intereses entre empresarios y trabajadores.

Stefano Magagnoli, profesor de la Universidad de Parma, en su artículo «Da Viaggio in Italia di Guido Piovene alla costituzione del Ministero del turismo: opinione pubblica e dibattito parlamentare», valora el hecho de que los días 18 y 19 de abril de 1993 más del $82 \%$ de los votantes apoyara la supresión de la Ley de 31 de julio de 1959 del Ministerio de Turismo y del Espectáculo, que había absorbido funciones asignadas a las regiones por la constitución.
Los profesores de la Universidad de Málaga, Marta Luque y Carmelo Pellejero, autores de «Inversión pública y desarrollo turístico en España durante el primer franquismo, 1939-1959», afirman que el primer franquismo fue un periodo de especial transcendencia para que España pudiera convertirse durante los años de 1960 en un destino turístico de masas, y es bastante significativo que el número de extranjeros entrados en España provistos de pasaporte se multiplicara por ocho entre 1946 y 1951.

En la segunda parte, dedicada a la sociedad y la economía, prosiguen los estudios de Adda Di Nucci, Paola Nardone y Natascia Ridolfi, que en su ensayo "All'alba di un nuovo inizio: I'Enitea tra progetti e Totalizzatore-referendum turistico negli anni'50 del Novecento» argumentan la liquidación en 1957 del Ente Nazionale Industrie Turistiche e Alberghiere al no haber sido capaz de renovarse y atender a los deseos, en este sentido, de todo el país. Donatella Strangio en su artículo «Turismo ed economía circolare in Italia» apunta que la actividad turística constituye un sistema integrado de conexiones que pueden aumentar el bienestar y la prosperidad local. De Martino L. Fagnani y Luciano Faffi, en su "Riconstruire l'Italia dopo la Seconda guerra mondiale: Turismo per giovani mutilati [...]", destacan el valor social de una fundación pionera respecto a la integración de jóvenes mutilados después de la guerra en relación con el fenómeno turístico. Ivanne Galant escribe «¿Bueno, bonito y barato? El turismo francés en España, 1945-1965», observando que los turistas arqueólogos, buscadores, según ellos mismos, de la verdadera España, criticaban a los turistas de la Costa Brava; pero que a la postre ampos tipos de turistas acabaron homogeneizando sus prácticas. Davide Bagnaresi, Francesco M. Barbini y Patrizia Battilani, en su estudio «La spiaggia come luogo di lavoro: Azienda di soggiorno [...]», desvelan que los balnearios en Italia durante la segunda mitad del siglo xx experimentaron cambios en la disposición de sus estructuras receptivas y recreativas. Marta Palau Rubio en su trabajo «La revista Barcelona Atracción, 1945-1954: entre la publicidad turística y la propaganda política» muestra que dicha publicación contribuyó a la configuración de imágenes nacionales y a la construcción de elementos turísticos, estructurando una sociedad receptora de turistas. Beatriz Correyero y Ascensión Miralles en su trabajo «El cartel de ferias y fiestas de Murcia al servicio de la propaganda turística de España, 1939-1959» indican la relevancia del turismo como factor unificador de las características regionales a tenor de una misma concepción cultural durante el primer franquismo. Elisabbeta Caroppo en su artículo «Sviluppo e limiti del turismo nel Mezzogiorno d’Italia negli anni de la Ricostruzioni [...]» refiere la importante ayuda estatal, acompañada de recursos procedentes de activos locales, dirigida a superar el retraso económico de la Italia meridional postbélica. Y Carmen Gil de Arriba aporta el estudio «Vínculos ideológicos entre turismo y arquitectura durante el primer 
franquismo. Una reflexión a través de la Revista Nacional de Arquitectura, 1941-1958», donde contrasta la situación turística de España en 1941, expresada por Luís Bolín en la Revista Nacional de Arquitectura, con el número específico de paradores, hospederías y albergues, de octubre de 1948, cuando comienza a menguar el intervencionismo del Estado.

Finalmente, en la tercera parte del libro, Bárbara Costa e Ilaria Pasotti destacan las fuentes sobresalientes en Italia, donde los archivos bancarios, como el propio del Banco de Nápoles, conforme indica Gloria Guida, son predominantes para la investigación de la historia del turismo. Las imágenes que se adjuntan al libro son realmente bellas y significativamente expresivas. Todos los artículos brindan una lúcida redacción, unos en castellano y la mayoría en italiano, facilitando la lectura e interpretación del interesante contenido de esta obra de análisis histórico comparado del turismo en dos de los países más importantes del sector.

En este libro observo originalidad temática e innovaciones en el método analítico. Aunque predomina el número de ensayos sobre el caso de Italia, las respectivas contribuciones son complementarias y ofrecen contrastes genuinos que, partiendo de algunas analogías históricas, confluyen en ofrecer una interpretación sólida acerca del origen del turismo en la Europa meridional, particularmente en la ribera mediterránea, que devino en constituir un sector económico de éxito, integrado por múltiples ramificaciones de empresas impulsoras de renta y empleo a escalas muy significativas para las economías de ambos países.

Pienso que la tarea está abierta a un proceso innovador de estudios biográficos de los empresarios, cuya genialidad emprendedora está pidiendo a gritos investigar con tino las categorías determinantes de su propia empresarialidad.

Juan Hernández Andreu

Universidad Autónoma de Madrid

https://doi.org/10.33231/j.ihe.2022.01.008 